\title{
An investigation on the role of ytterbium in ytterbium promoted y-alumina-supported nickel catalysts for dry reforming of methane
}

Amin, Mohamad Hassan; Tardio, James; Bhargava, Suresh

https://researchrepository.rmit.edu.au/esploro/outputs/9921860108201341/filesAndLinks?institution=61RMIT_INST\&index=null

Amin, M. H., Tardio, J., \& Bhargava, S. (2013). An investigation on the role of ytterbium in ytterbium promoted y-alumina-supported nickel catalysts for dry reforming of methane. International Journal of Hydrogen Energy, 38(33), 14223-14231. https://doi.org/10.1016/j.ijhydene.2013.08.040

Document Version: Published Version

Published Version: https://doi.org/10.1016/j.ijhydene.2013.08.040

Repository homepage: https://researchrepository.rmit.edu.au This is an open-access article distributed under the terms of the Creative Commons Attribution-NonCommercial-No Derivative Works License, which permits non-commercial use, distribution, and reproduction in any medium, provided the original author and source are credited. Copyright (c) 2013, Hydrogen Energy Publications, LLC. Published by Elsevier Ltd. All rights reserved. Downloaded On 2023/04/26 15:45:42 +1000 
Thank you for downloading this document from the RMIT Research Repository.

The RMIT Research Repository is an open access database showcasing the research outputs of RMIT University researchers.

RMIT Research Repository: http://researchbank.rmit.edu.au/

\section{Citation:}

Amin, M, Tardio, J and Bhargava, S 2013, 'An investigation on the role of ytterbium in ytterbium promoted y-alumina-supported nickel catalysts for dry reforming of methane', International Journal of Hydrogen Energy, vol. 38, no. 33, pp.

14223-14231.

See this record in the RMIT Research Repository at:

https://researchbank.rmit.edu.au/view/rmit:24104

Version: Published Version

\section{Copyright Statement:}

(c) This is an open-access article distributed under the terms of the Creative Commons Attribution-NonCommercial-No Derivative Works License, which permits non-commercial use, distribution, and reproduction in any medium, provided the original author and source are credited. Copyright $\odot$ 2013, Hydrogen Energy Publications, LLC. Published by Elsevier Ltd. All rights reserved.

\section{Link to Published Version:}

http://dx.doi.org/10.1016/j.ijhydene.2013.08.040 


\title{
An investigation on the role of ytterbium in ytterbium promoted $\gamma$-alumina-supported nickel catalysts for dry reforming of methane ${ }^{2\}}$
}

\author{
Mohamad Hassan Amin, James Tardio, Suresh K. Bhargava* \\ Centre for Advanced Materials \& Industrial Chemistry, School of Applied Sciences, RMIT University, Melbourne, VIC \\ 3001, Australia
}

\section{A R T I C L E I N F O}

Article history:

Received 28 March 2013

Received in revised form

22 July 2013

Accepted 7 August 2013

Available online 18 September 2013

Keywords:

$\mathrm{CO}_{2}$ reforming of methane

Ytterbium

$\mathrm{Ni} / \gamma-\mathrm{Al}_{2} \mathrm{O}_{3}$ catalyst

Promoter

\begin{abstract}
A B S T R A C T
Addition of low quantities of ytterbium to sol-gel prepared $\mathrm{Ni} / \gamma-\mathrm{Al}_{2} \mathrm{O}_{3}$ catalysts has been shown to lead to significant increases in catalytic activity and long term stability in the catalytic conversion of $\mathrm{CO}_{2}$ and $\mathrm{CH}_{4}$ into syngas $\left(\mathrm{H}_{2}\right.$ and $\left.\mathrm{CO}\right)$. The role of ytterbium in these catalysts was investigated in this study through detailed investigations on the structure and composition of ytterbium promoted $\mathrm{Ni} / \gamma-\mathrm{Al}_{2} \mathrm{O}_{3}$ catalysts using the following techniques: synchrotron X-ray diffraction, X-ray Photoemission Spectroscopy, Transmission Electron Microscopy, Scanning Electron Microscopy/Energy Dispersive X-ray analysis, Temperature Programmed Reduction techniques and $\mathrm{N}_{2}$ adsorption-desorption isotherms. The results obtained indicated that ytterbium, at small quantities (up to $2 \mathrm{wt} \%$ ), interacted strongly with the support which in turn altered the interaction between nickel and the support (most notably it was found to completely inhibit the formation of $\mathrm{NiAl}_{2} \mathrm{O}_{4}$ ). This decreased interaction between $\mathrm{Ni}$ and the support also led to a higher quantity of $\mathrm{Ni}$ being present in the catalyst in the form of Ni.
\end{abstract}

Copyright @ 2013, Hydrogen Energy Publications, LLC. Published by Elsevier Ltd. All rights

reserved.

\section{Introduction}

In recent years there has been renewed attention in $\mathrm{CO}_{2} /$ dry reforming of methane $\left(\mathrm{CH}_{4(\mathrm{~g})}+\mathrm{CO}_{2(\mathrm{~g})} \leftrightarrow 2 \mathrm{CO}_{(\mathrm{g})}+2 \mathrm{H}_{2(\mathrm{~g})}\right)$, due to potential environmental benefits of utilising $\mathrm{CO}_{2}$, the need to obtain clean and sustainable energy and an increase in demand for syngas $\left(\mathrm{H}_{2} / \mathrm{CO}\right)[1,2] . \mathrm{CO}_{2} /$ dry reforming of methane (DRM) is a promising process that could potentially be used to convert $\mathrm{CO}_{2}$ from concentrated carbon dioxide waste streams into a valuable product, syngas, which is the basic building block for many valuable chemicals [1-3]. In comparison to conventional steam reforming or partial oxidation of methane, DRM is more appropriate in remote natural gas or crude oil fields, where water supplies are limited. These gases can be obtained without any fossil fuel involvement, e.g. with anaerobic biological sludge and organic waste decomposition [4]. Catalytic $\mathrm{CO}_{2}$ reforming of methane has however not been established as an industrial process. This is predominantly due to the lack of development of a commercially viable catalyst(s) for this process.

Of the numerous materials that have been investigated for catalysing the dry reforming of methane, the most successful

is This is an open-access article distributed under the terms of the Creative Commons Attribution-NonCommercial-No Derivative Works License, which permits non-commercial use, distribution, and reproduction in any medium, provided the original author and source are credited.

* Corresponding author. Tel.: +61 39925 3365; fax: +61 399253747.

E-mail address: suresh.bhargava@rmit.edu.au (S.K. Bhargava).

0360-3199/\$ - see front matter Copyright @ 2013, Hydrogen Energy Publications, LLC. Published by Elsevier Ltd. All rights reserved. http://dx.doi.org/10.1016/j.ijhydene.2013.08.040 
to date, include noble metal (Pt, $\mathrm{Pd}, \mathrm{Rh}, \mathrm{Ru})$ supported catalysts and Ni based catalysts. Ni based catalysts in particular have been the subject of a numerous studies due to their relatively low cost and similar activity and selectivity compared to the most active noble metal supported catalysts [1-7]. The main practical drawback of Ni based catalysts is their high susceptibility to carbon deposition/formation of "inactive" carbon [1-3]. In order to overcome/improve the aforementioned significant improvements in the properties of deposited Ni are necessary. One of the major factors that influences the properties of $\mathrm{Ni}$ in $\mathrm{Ni}$ based catalysts that has been identified previously is the interaction of the Ni precursor $\left(\mathrm{Ni}^{2+}\right)$ with the support. This has been shown to have a significant effect on the reduction of $\mathrm{Ni}^{2+}$, a key step in the formation of active $\mathrm{Ni}$, and the subsequent characteristics of the deposited Ni particles [8,9].

To improve the activity and stability of $\mathrm{Ni}$ based catalysts for the dry reforming of methane researchers have focused mostly on the discovery of better supports [2,10-12] and the discovery of suitable promoters/Ni based bi-metallic catalysts $[8,12,13]$. Promoters for Ni based catalysts that have been studied include alkali [5,6], alkaline earth [5], transition metal $[5,7,14]$ and rare earth metal oxides [15-20]. Ni based catalysts containing multiple metals/oxides from different groups have also been investigated [9-11,14,20].

Recently it was reported that the introduction of a low level of $\mathrm{Yb}\left(2 \mathrm{wt} \%\right.$ ) as promoter to a $\mathrm{Ni} / \gamma-\mathrm{Al}_{2} \mathrm{O}_{3}$ catalyst (prepared via a sol-gel method) leads to superior catalytic activity and stability [1]. In this work the role of ytterbium as promoter on alumina-supported nickel catalyst prepared by a sol-gel process for catalysing the dry reforming of methane has been investigated through comprehensive studies on the structure/ composition/properties of the materials containing varying amounts of ytterbium. The aforementioned was investigated using the following techniques: synchrotron X-Ray diffraction (XRD), X-ray Photoemission Spectroscopy (XPS), Transmission Electron Microscopy (TEM), Scanning Electron Microscopy (SEM), Temperature Programmed Reduction (TPR) techniques and $\mathrm{N}_{2}$ adsorption-desorption isotherms.

\section{Experimental}

\subsection{Catalyst preparation}

$\mathrm{Ni}(20 \mathrm{wt} \%) / \gamma-\mathrm{Al}_{2} \mathrm{O}_{3}$ containing varying amounts of $\mathrm{Yb}(0-4 \mathrm{wt}$ $\%)$ was prepared using a sol-gel method reported earlier [1]. Materials were also subjected to a reduction process to simulate that used in the activation of Ni based catalysts prior to use in catalytic dry reforming. This process involved exposing catalysts to a mixed flow of $\mathrm{H}_{2}$ and $\mathrm{He}$ (10:40 $\left.\mathrm{mL} \mathrm{min}^{-1}\right)$ at $700{ }^{\circ} \mathrm{C}$ for $2 \mathrm{~h}$. Such catalysts are hereafter referred to as reduced catalysts.

\subsection{Characterisation}

Synchrotron X-ray diffraction patterns were obtained using the X-ray diffraction instrument at the Australian Synchrotron using a photon energy of $17.03 \mathrm{keV}(0.72888 \AA)$. A Mythen microstrip detector, which required each pattern to be taken in two parts with an acquisition time of $180 \mathrm{~s}$, was used. These patterns were later merged together to produce the full pattern.

Electron microscopy was performed using a transmission electron microscope, JEOL 2010 TEM, and a scanning electron microscope, FEI Nova NanoSEM operated at $30 \mathrm{kV}$, equipped with an X-ray dispersive (EDX) spectrometer.

Physical characteristics of calcined catalysts were studied by nitrogen adsorption-desorption analysis at $77 \mathrm{~K}$ using a Micromeritics ASAP 2010 instrument. Before measurements, samples were degassed under vacuum at room temperature for 30 min with slow degassing, followed by fast mode degassing at $280^{\circ} \mathrm{C}$ overnight.

$\mathrm{X}$-ray photoelectron spectra, Thermo Scientific K-Alpha XPS spectrometer, were recorded using $\mathrm{Al} \mathrm{K} \alpha(E=1486.6 \mathrm{eV})$ radiation. The binding energy of the $\mathrm{C} 1 \mathrm{~s}$ level arising from the hydrocarbons adsorbed onto the surface of pure $\gamma$-alumina and $\mathrm{Ni} / \gamma-\mathrm{Al}_{2} \mathrm{O}_{3}$ was set to $285.0 \mathrm{eV}$, therefore all binding energies from the core levels of different elements were referenced to the $\mathrm{C} 1 \mathrm{~s}$ line.

Temperature-programmed reduction (TPR) profiles of calcined catalysts were obtained using a quartz reactor (I.D. $4.5 \mathrm{~mm})$, packed with $50 \mathrm{mg}$ catalyst in a flow $\left(20 \mathrm{~mL} \mathrm{~min}^{-1}\right)$ of $\mathrm{H}_{2}-$ Ar mixture $\left(4.14 \mathrm{~mol} \% \mathrm{H}_{2}\right.$ ) from $135^{\circ} \mathrm{C}$ to $970{ }^{\circ} \mathrm{C}$ at a linear heating rate of $10{ }^{\circ} \mathrm{C} \mathrm{min}{ }^{-1}$. The $\mathrm{H}_{2}$ consumed was measured quantitatively by a Thermal Conductivity Detector (TCD). Prior to TPR analysis materials were pretreated at $500{ }^{\circ} \mathrm{C}$ for $1 \mathrm{~h}$ under a flow $\left(20 \mathrm{~cm}^{3} \mathrm{~min}^{-1}\right)$ of argon.

\section{Results and discussion}

\subsection{Effect of ytterbium loading on characteristics of $\mathrm{Ni}$ / $\gamma-\mathrm{Al}_{2} \mathrm{O}_{3}$ catalysts}

\subsubsection{Nitrogen adsorption-desorption studies}

The nitrogen adsorption-desorption isotherms and $\mathrm{BJH}$ pore size distribution obtained for non-doped and ytterbiumdoped $\mathrm{Ni} / \gamma-\mathrm{Al}_{2} \mathrm{O}_{3}$, prior to reduction - refer to section 2.1, are displayed in Fig. $1(\mathrm{a}$ and $\mathrm{b})$, respectively. According to IUPAC classifications, all samples exhibit type IV isotherms with $\mathrm{H} 1$ shaped hysteresis loops, which are characteristic of materials having uniform "cylindrical shaped" pores in the framework [21]. The textural characteristics obtained from the nitrogen adsorption-desorption studies are given in Table 1. It is clearly seen that the textural properties of the $\mathrm{Ni} / \gamma-\mathrm{Al}_{2} \mathrm{O}_{3}$ material were affected by the introduction of $\mathrm{Yb}$, which is indicative of the $\mathrm{Yb}$ interacting with the support. From the data given in Table 1 it can be observed that all the Yb doped materials had a significantly lower pore volume, $0.16 \mathrm{~cm}^{3} \mathrm{~g}^{-1}$, as compared to the undoped materials, $0.23 \mathrm{~cm}^{3} \mathrm{~g}^{-1}$. This decrease in pore volume was most likely due to the interaction of $\mathrm{Yb}$ with the alumina support. The $\mathrm{Yb}$ doped materials also had significantly narrower pore size distributions, predominantly in the range of $\sim 3.5-3.7 \mathrm{~nm}$, and smaller pores compared to the un-doped material (Table 1). This is indicative of the formation and segregation of $\mathrm{NiO}$ distributed inside the pores and in the vicinity of alumina grain boundaries $[22,23]$, which is discussed in more detail in the next section. 

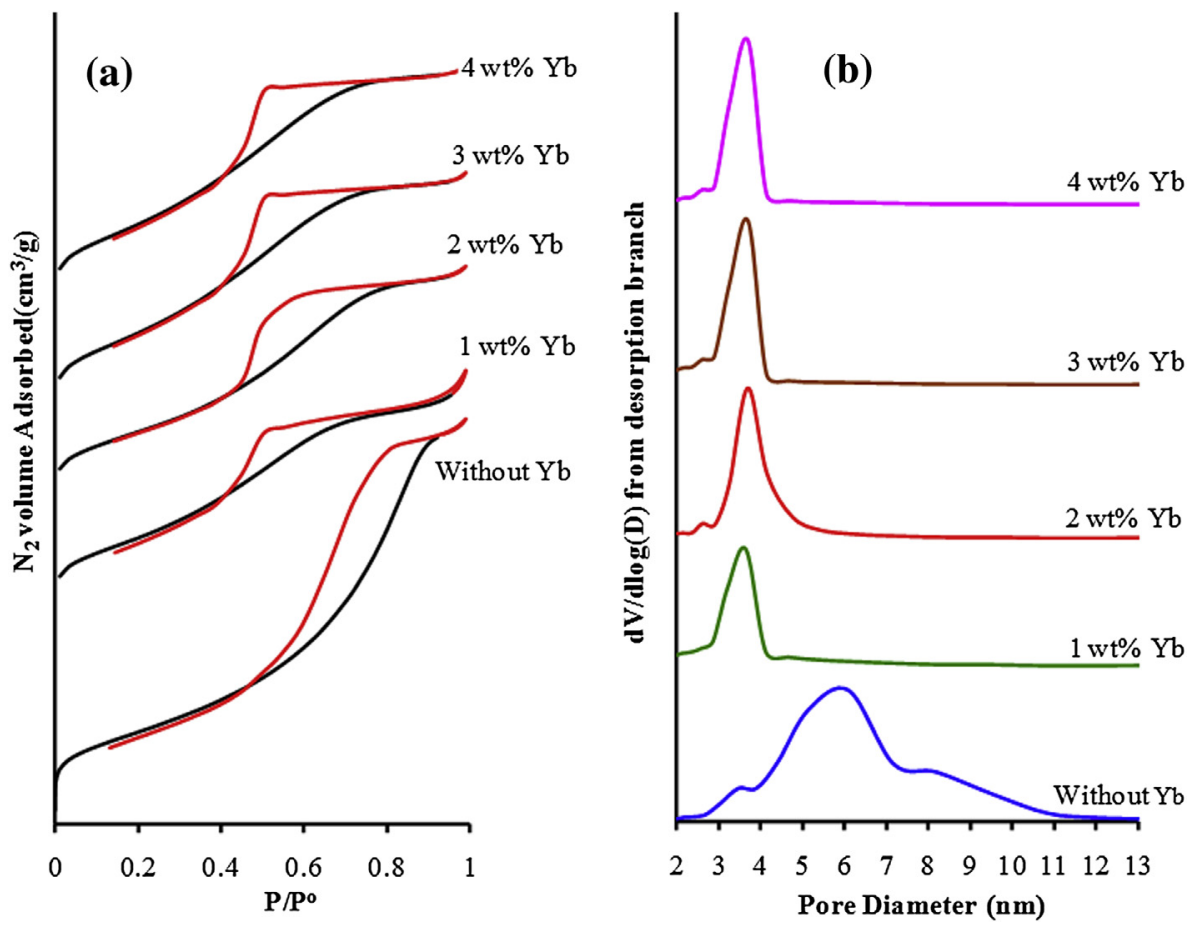

Fig. 1 - (a) Adsorption-desorption isotherms and (b) $\mathrm{BJH}$ pore size distribution (desorption data) at $77 \mathrm{~K}$ of $\mathrm{Ni} / \gamma-\mathrm{Al}_{2} \mathrm{O}_{3}$ catalysts with different $\mathrm{Yb}$ loading.

\subsubsection{X-ray diffraction analysis}

XRD patterns of the as-prepared materials, prior to being reduced, are shown in Fig. 2. The XRD pattern of non-doped $\mathrm{Ni} / \gamma-\mathrm{Al}_{2} \mathrm{O}_{3}$ confirms the presence of $\gamma-\mathrm{Al}_{2} \mathrm{O}_{3}$ and $\mathrm{NiAl}_{2} \mathrm{O}_{4}$ phases, and a small amount of $\mathrm{NiO}$, line observed at $\mathrm{d}$ value of

Table 1 - Textural properties, crystallite size and particle size of nickel species in $\mathrm{Ni} / \gamma-\mathrm{Al}_{2} \mathrm{O}_{3}$ catalysts with

different $\mathrm{Yb}$ loading (discussions on Ni crystallite size and particle size are provided in Ref. [1]).

\begin{tabular}{|c|c|c|c|c|c|}
\hline Yb load (wt\%) & 0 & 1 & 2 & 3 & 4 \\
\hline $\begin{array}{l}\text { BET surface area } \\
\left(\mathrm{m}^{2} \mathrm{~g}^{-1}\right)\end{array}$ & 124 & 134 & 136 & 158 & 158 \\
\hline $\begin{array}{l}\text { Average pore radius } \\
(\mathrm{nm})^{\mathrm{a}}\end{array}$ & 8.17 & 4.95 & 4.89 & 4.38 & 4.37 \\
\hline $\begin{array}{l}\text { Average pore volume } \\
\qquad\left(\mathrm{cm}^{3} \mathrm{~g}^{-1}\right)^{\mathrm{b}}\end{array}$ & 0.23 & 0.15 & 0.15 & 0.16 & 0.16 \\
\hline $\begin{array}{l}\text { NiO (non-reduced } \\
\text { catalysts) }^{c}\end{array}$ & 15.6 & 15.9 & 16.2 & 16.8 & 18.1 \\
\hline $\begin{array}{l}\text { Nio (reduced } \\
\text { catalysts) }^{c}\end{array}$ & 15.9 & 13.4 & 11.5 & 11.7 & 15.3 \\
\hline $\begin{array}{l}\text { Average particle } \\
\text { size of Nio }\end{array}$ & 16.6 & 14.5 & 12.0 & 12.2 & 15.6 \\
\hline \multicolumn{6}{|c|}{$\begin{array}{l}\text { a Average of adsorption and desorption average pore diameter ( } 4 \mathrm{~V} / \mathrm{A} \\
\text { by BET). } \\
\mathrm{b} \text { Average of adsorption and desorption single point total pore } \\
\text { volume of pores. } \\
\text { c Measured by X-ray diffraction line broadening method and } \\
\text { Scherrer formula (nm). } \\
\text { d Average particle size of Nio as observed from the TEM images } \\
(\mathrm{nm}) \text {. }\end{array}$} \\
\hline
\end{tabular}

$2.088 \AA$ was assigned to the (012) reflection of nickel oxide. The $\mathrm{XRD}$ patterns of the $\mathrm{Yb}$-doped materials exhibit diffractions lines corresponding to $\gamma-\mathrm{Al}_{2} \mathrm{O}_{3}$ (PDF card \# 01-1303) and $\mathrm{NiO}$ phases (PDF card \# 44-1159) and the reduction of diffraction lines corresponding to the $\mathrm{NiAl}_{2} \mathrm{O}_{4}$ spinel phase. The reduction of $\mathrm{NiAl}_{2} \mathrm{O}_{4}$ in the $\mathrm{Yb}$ doped materials supports that the addition of $\mathrm{Yb}$ affects the interaction of nickel with the alumina support. It can also clearly be seen in the XRD patterns obtained that the relative intensity ratios of the main diffraction line of $\mathrm{NiO}(012)$ to the main diffraction line of $\gamma$ $\mathrm{Al}_{2} \mathrm{O}_{3}$ (211), in the materials containing 1 and $2 \% \mathrm{Yb}$, clearly increased with increasing concentration of $\mathrm{Yb}$. This result indicates that the addition of $\mathrm{Yb}$ up to $2 \mathrm{wt} \%$ on $\mathrm{Ni} / \gamma-\mathrm{Al}_{2} \mathrm{O}_{3}$ influences the interaction of the metal with the framework of the support and contributes to the formation of separate phases of $\gamma-\mathrm{Al}_{2} \mathrm{O}_{3}$ and $\mathrm{NiO}$. Interestingly the addition of a higher amount of ytterbium ( 3 and $4 \mathrm{wt} \%$ ) did not result in a similar trend. This is most likely due to the doping of more than $2 \mathrm{wt} \% \mathrm{Yb}$ leading to the formation of a secondary phase of ytterbium oxide which reduces the influence of $\mathrm{Yb}$ doping, which is discussed in section 3.1.4. No ytterbium oxide diffraction lines in the XRD pattern of the materials doped with $>2 \mathrm{wt} \% \mathrm{Yb}$ were observed as the amount present was most likely below the detection limit of the XRD instrument.

The XRD patterns obtained for the non-doped and Yb-doped materials after being reduced under similar conditions to those used to activated $\mathrm{Ni}$ based catalysts for use in the dry reforming reaction, refer to Experimental section, are presented in Fig. 3. Interestingly the undoped materials did not show any diffraction lines that correspond to metallic Ni. Conversely the XRD patterns of the $\mathrm{Yb}$ doped materials contained strong XRD lines representative of metallic $\mathrm{Ni}$, at $\mathrm{d}$ values of $2.034,1.762,1.246$ 


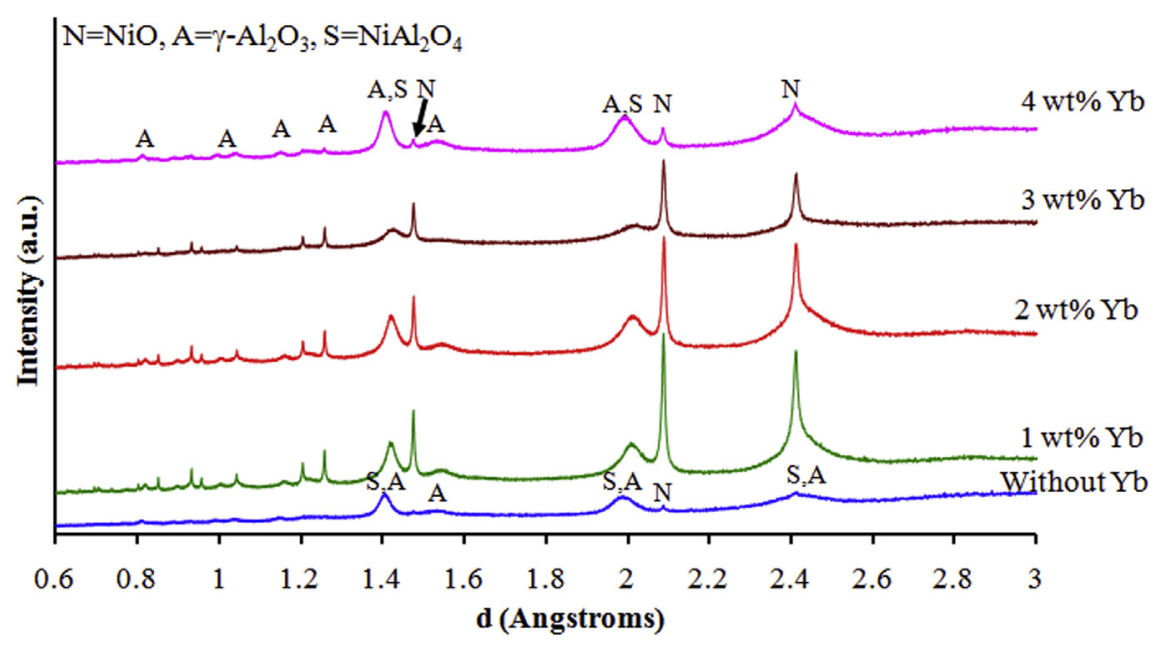

Fig. 2 - Synchrotron XRD patterns of pre-reduced non-doped and $\mathrm{Yb}$-doped $\mathrm{Ni} / \gamma-\mathrm{Al}_{2} \mathrm{O}_{3}$ samples.

and $1.062 \AA$ corresponding to the (111), (200), (220) and (311) planes of cubic phase of metallic $\mathrm{Ni}^{0}$ (PDF card \# 04-0850). The relative intensity ratios of the main diffraction lines of $\mathrm{Ni}$ (111) and $\gamma-\mathrm{Al}_{2} \mathrm{O}_{3}(211)$ revealed that the intensity of the Ni diffraction lines increased with increasing amount of $\mathrm{Yb}$, up to $3 \mathrm{wt} \%$.

\subsubsection{Microstructural analysis}

TEM/EDX analysis was conducted on un-doped and ytterbium doped catalysts in order to further investigate the influence of $\mathrm{Yb}$ doping, Fig. 4 - refer to labelled points. This analysis confirmed the presence of a nickel aluminate compound in the non-doped catalyst and nickel phases in ytterbium-doped catalysts. In addition, EDX spot analysis results obtained for the alumina support clearly showed the presence of $\mathrm{Ni}$ and $\mathrm{Yb}$ in this area. The aforementioned identification of $\mathrm{Yb}$ in the $\mathrm{Yb}$ doped $\mathrm{Ni}$ catalyst in a highly dispersed form among the framework, is consistent with the $\mathrm{Yb}$ in the doped materials not being detectable using XRD. Moreover, a uniform dispersion of the bulk NiO particles among the alumina framework can also be clearly seen in the Yb doped material, the presence of white coloured ytterbium phase around the grey coloured nickel phase grains is confirmed by back-scattered SEM/EDX (Fig. 5).

These results suggest that $\mathrm{Yb}$ doping acts as a barrier between the $\mathrm{Ni}$ and alumina support. This $\mathrm{Yb}$ most likely plays a significant role in hindering the formation of spinel $\mathrm{NiAl}_{2} \mathrm{O}_{4}$, and hence the maintaining of separate phases of $\gamma-\mathrm{Al}_{2} \mathrm{O}_{3}$ and $\mathrm{NiO} / \mathrm{Ni}$. This hindering of the formation of spinel is most likely due to the Yb doping occurring predominantly at the surface of alumina and that this surface doped alumina does not readily react with $\mathrm{Ni}$ to form spinel.

\subsubsection{XPS analysis}

XPS spectra obtained for the non-doped and Yb doped catalysts are presented in Fig. 6 . The Ni 2p, Al 2p and $\mathrm{Yb} 4 \mathrm{~d}$ core level spectra of the catalysts are displayed in Fig. $6 \mathrm{a}-\mathrm{c}$. For the non-doped $\mathrm{Ni} / \mathrm{Al}_{2} \mathrm{O}_{3}$ catalysts, the $\mathrm{Ni} 2 \mathrm{p}_{3 / 2}$ and $\mathrm{Al} 2 \mathrm{p}$ peaks seen at $856.1 \mathrm{eV}$ and $74.3 \mathrm{eV}$, respectively correspond to the

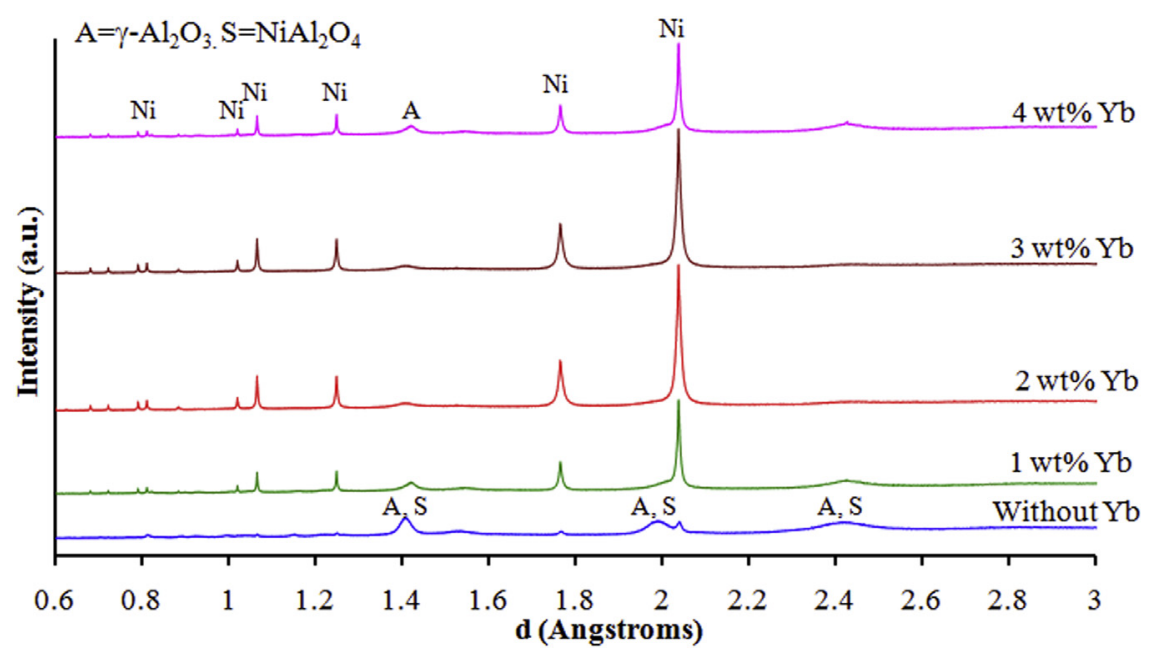

Fig. 3 - Synchrotron XRD patterns of reduced non-doped and $\mathrm{Yb}$-doped $\mathrm{Ni} / \gamma-\mathrm{Al}_{2} \mathrm{O}_{3}$ samples. 

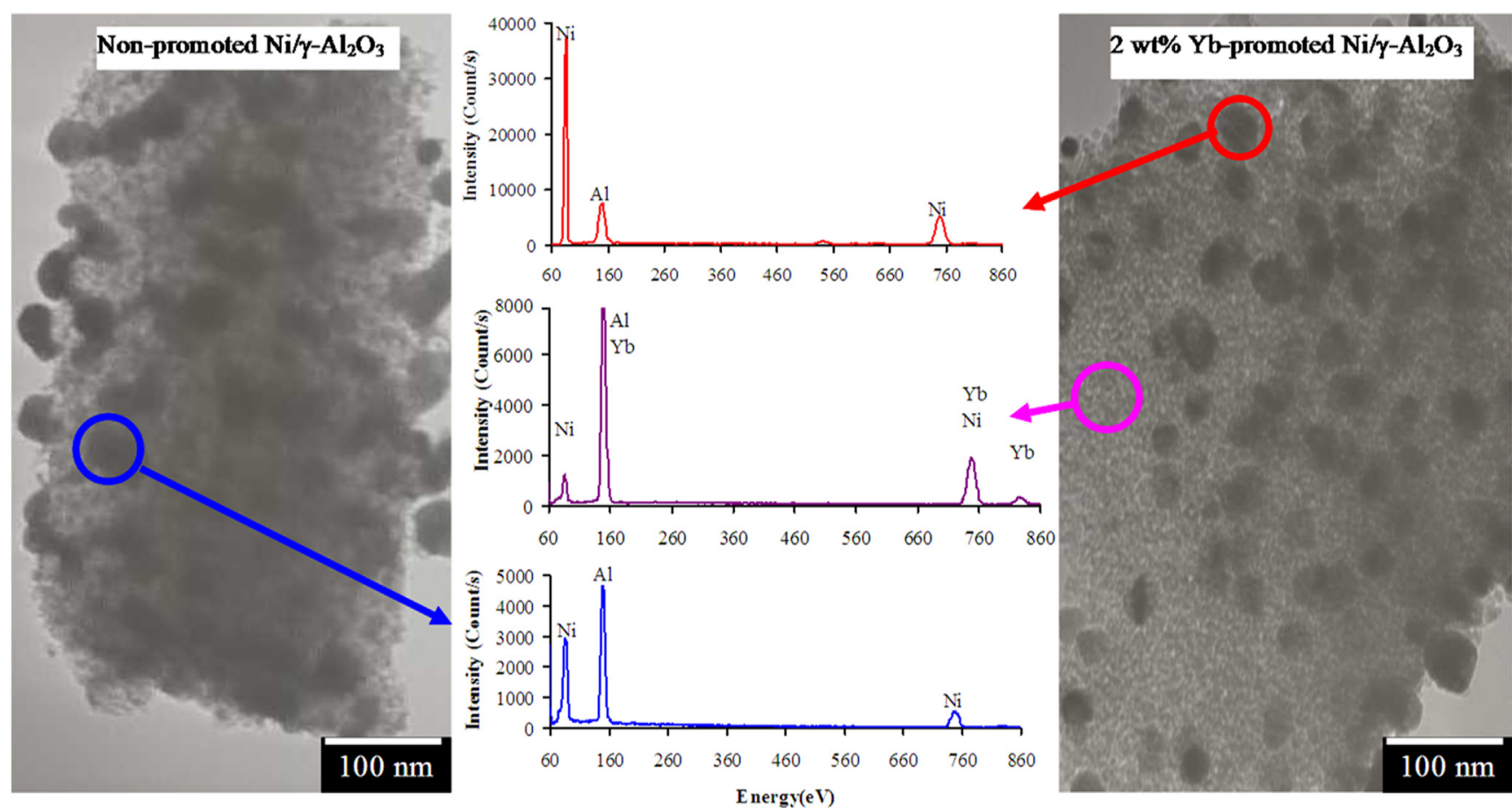

Fig. 4 - TEM and EDX of indicated area for non-promoted and $2 \mathrm{wt} \% \mathrm{Yb}$-promoted $\mathrm{Ni} / \gamma-\mathrm{Al}_{2} \mathrm{O}_{3}$ catalyst.

values associated with $\mathrm{Ni}$ in the form of $\mathrm{NiAl}_{2} \mathrm{O}_{4}$ indicating that $\mathrm{Ni}^{2+}$ on the surface exists in the form of $\mathrm{NiAl}_{2} \mathrm{O}_{4}$. It can be observed that the binding energy of Ni decreased when 1 and $2 \mathrm{wt} \% \mathrm{Yb}$ were doped. This corresponds to Ni being in the form of NiO. The Ni $2 \mathrm{p}$ and $\mathrm{Al} 2 \mathrm{p}$ spectra of the $2 \mathrm{wt} \% \mathrm{Yb}$ doped $\mathrm{Ni} / \mathrm{Al}_{2} \mathrm{O}_{3}$ catalyst exhibit features that are assigned to $\mathrm{NiO}$ and $\gamma-\mathrm{Al}_{2} \mathrm{O}_{3}$ with $\mathrm{Ni} 2 \mathrm{p}_{3 / 2}$ and $\mathrm{Al} 2 \mathrm{p}$ binding energies at 854.9 and $73.9 \mathrm{eV}$, respectively [24,25]. A broader peak located at $861.8 \mathrm{eV}$ due to a strong shake-up process accompanies the $\mathrm{Ni} 2 \mathrm{p}_{3 / 2}$ signal corresponding to $\mathrm{Ni}^{2+}$. This result suggested that the addition of ytterbium on $\mathrm{Ni} / \mathrm{Al}_{2} \mathrm{O}_{3}$ prevents the reaction between $\gamma-\mathrm{Al}_{2} \mathrm{O}_{3}$ and $\mathrm{NiO}$ and leads to the formation of separate phases of $\gamma-\mathrm{Al}_{2} \mathrm{O}_{3}$ and $\mathrm{NiO}$ as confirmed by XRD. Interestingly the addition of high amount of ytterbium (3 wt\% and more) did not achieve similar trend as those observed in the lower level doped catalysts. As shown in Fig. $6 a$ and $b$ the Ni $2 p$, Al $2 p$ electron binding energy increased slightly with introducing more than $2 \mathrm{wt} \% \mathrm{Yb}$ doping suggesting a decrease in the influence of $\mathrm{Yb}$ doping in the $\mathrm{Ni} / \mathrm{Al}_{2} \mathrm{O}_{3}$ catalyst.

The $\mathrm{Yb} 4 \mathrm{~d}$ spectra of the catalysts containing 1 and $2 \mathrm{wt} \%$ $\mathrm{Yb}$ show a weak peak at $184.3 \mathrm{eV}$ which can be attributed to
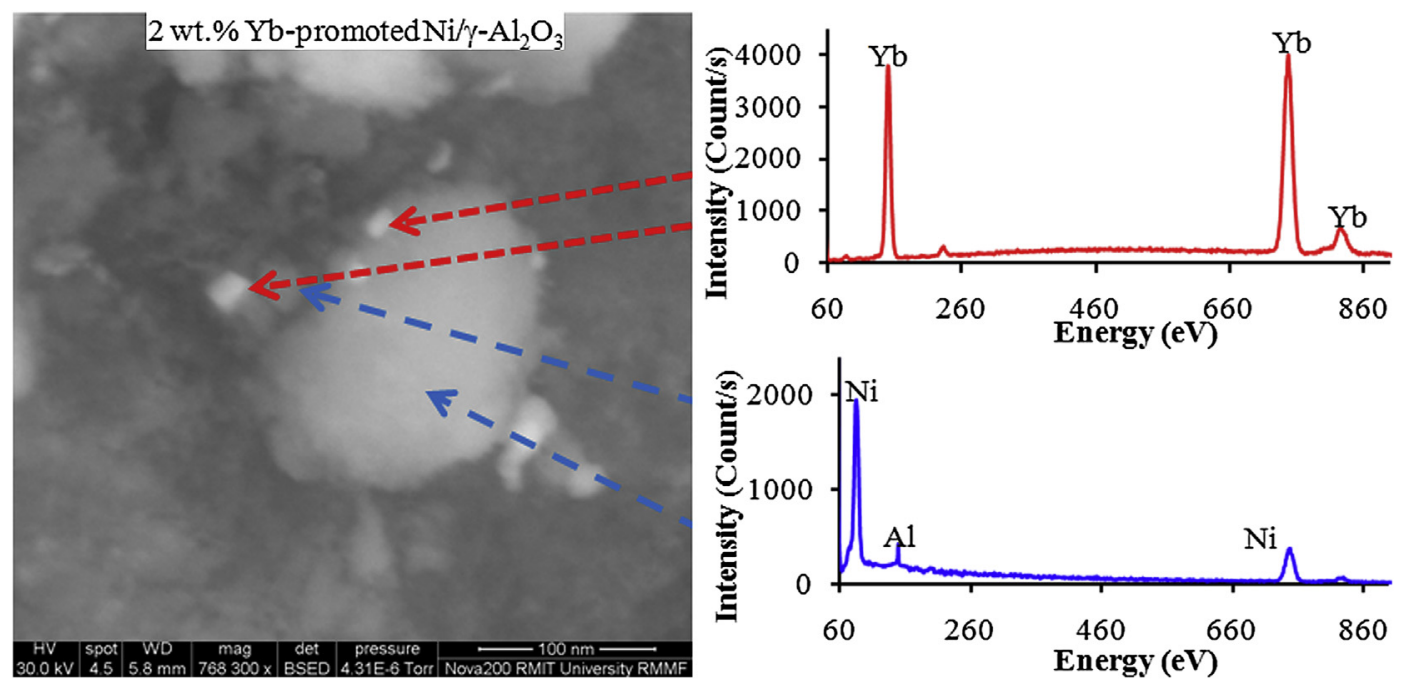

Fig. 5 - Back-scattered SEM image and EDX of indicated area for $2 \mathrm{wt} \% \mathrm{Yb}$-promoted $\mathrm{Ni} / \gamma-\mathrm{Al}_{2} \mathrm{O}_{3}$ catalyst. 


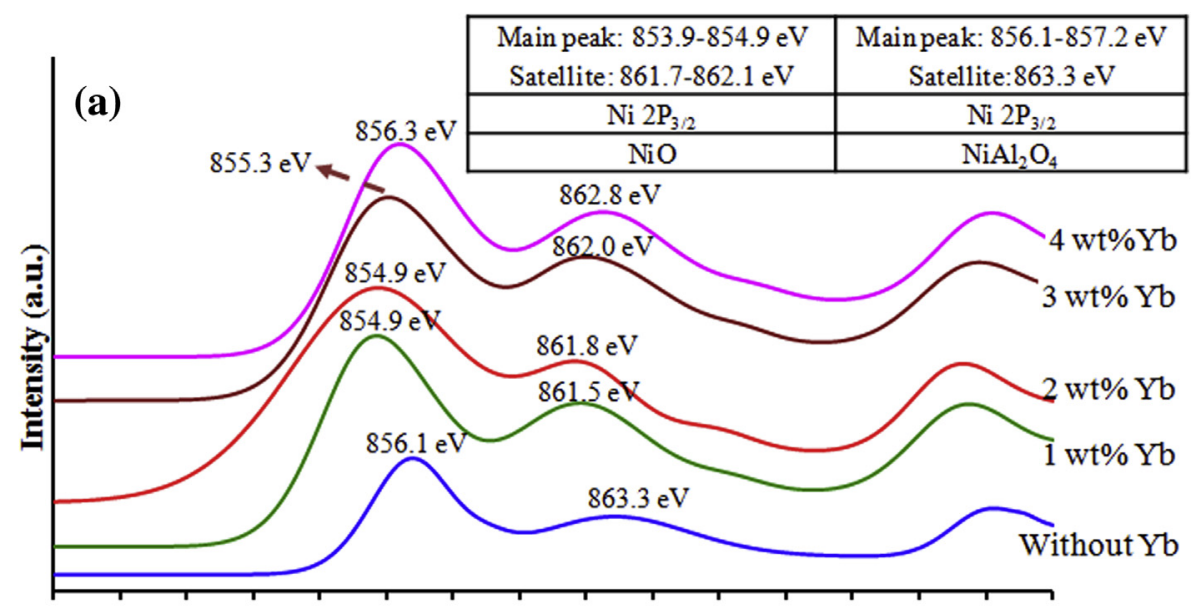

$846848 \quad 850852854856858860862864866868870872874876$

Binding energy (eV)
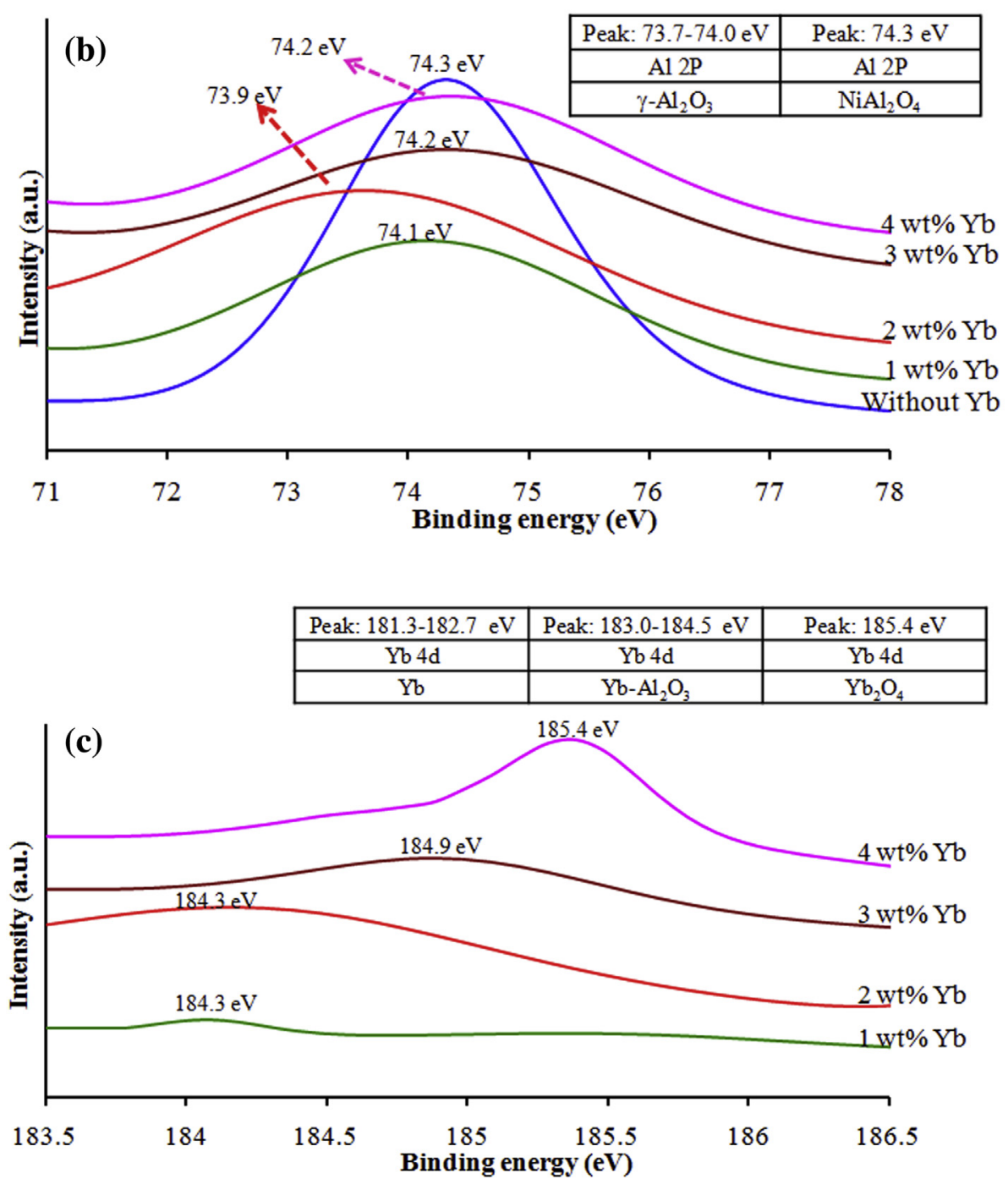

Fig. 6 - XPS spectra of the (a) Ni 2p, (b) Al 2p and (c) Yb $4 \mathrm{~d}$ in the pre-reduced catalysts. The inset table gives the relevant species for the labeled peaks [24-28]. 
Table 2 - Characteristic properties of $\mathrm{Ni} / \gamma-\mathrm{Al}_{2} \mathrm{O}_{3}$ catalysts with different $\mathrm{Yb}$ loading.

\begin{tabular}{lccccc} 
Yb load (wt\%) & 0 & 1 & 2 & 3 & 4 \\
\hline $\mathrm{ANi}^{0} /\left(\mathrm{ANi}^{0}+\mathrm{ANi}^{2+}\right)$ & 0.425 & 0.384 & 0.712 & 0.811 & 0.435 \\
\hline
\end{tabular}

the binding energy of highly dispersed $\mathrm{Yb}$ within the surface region of the alumina support framework. The Yb 4d peak position is however shifted to a higher binding energy when more than $2 \mathrm{wt} \%$ of $\mathrm{Yb}$ was doped, and reached $185.4 \mathrm{eV}$ for the material containing $4 \mathrm{wt} \% \mathrm{Yb}$. This is characteristic of $\mathrm{Yb}$ in the form of $\mathrm{Yb}_{2} \mathrm{O}_{3}$ [26-28] and indicates that a loading of more than $2 \mathrm{wt} \% \mathrm{Yb}$ results in the formation of $\mathrm{Yb}_{2} \mathrm{O}_{3}$ within the surface region of the catalyst. The aforementioned findings are consistent with solid solubility limit for $\mathrm{Yb}$ in $\mathrm{Al}_{2} \mathrm{O}_{3}$ / the phenomenon of doping ions forming a secondary phase when the doping ion concentration is greater than its solid solubility [29], as the solid solubility limit of $\mathrm{Yb}$ in $\mathrm{Al}_{2} \mathrm{O}_{3}$ has been reported as $\sim 2 \mathrm{wt} \%$ [30-33]. Deconvolution of the Ni $2 \mathrm{p}$ spectra of reduced catalysts was performed by Gaussian-Lorentzian curve-fitting to determine the peak areas $\left(\mathrm{ANi}^{\circ}\right.$ and $\left.\mathrm{ANi}^{2+}\right)$ and obtain relative surface concentrations of nickel species [34]. The ratio of peak areas $\mathrm{ANi}^{\circ}$ \% $\left(\mathrm{ANi}^{0}+\mathrm{ANi}^{2+}\right)$ can be used to illustrate the degree of reducibility of $\mathrm{Ni}^{2+}$ [34]. An increase in the $\mathrm{ANi}^{0} /\left(\mathrm{ANi}^{0}+\mathrm{ANi}^{2+}\right)$ ratio for ytterbium-promoted $\mathrm{Ni} / \gamma-\mathrm{Al}_{2} \mathrm{O}_{3}$ catalysts is seen after reduction compared to that of the un-promoted catalyst, indicative of an enhancement in the ease at which the $\mathrm{Ni}^{2+}$ in the catalysts containing $\mathrm{Yb}$ is reduced (Table 2).

\subsubsection{Temperature programmed reduction studies}

The reducibility of the non-promoted and $\mathrm{Yb}$-promoted $\mathrm{Ni} / \gamma$ $\mathrm{Al}_{2} \mathrm{O}_{3}$ catalysts was studied directly using temperatureprogrammed reduction (TPR). Fig. 7 shows the TPR profiles of the catalysts and a non-supported NiO for comparison. The TPR profile for NiO shows that reduction of the Ni started at $\sim 240{ }^{\circ} \mathrm{C}$ and reached a maximum rate at $\sim 400{ }^{\circ} \mathrm{C}$. The TPR profiles of all the catalysts consisted of two clear reduction temperature zones. The low temperature zone $\left(340-510^{\circ} \mathrm{C}\right)$ is attributed to the reduction of bulk $\mathrm{NiO}$ particles that did not interact with $\mathrm{Al}_{2} \mathrm{O}_{3}$, and the high temperature zone $\left(545-950{ }^{\circ} \mathrm{C}\right.$ ) represents the reduction of non-stoichiometric and stoichiometric $\mathrm{NiAl}_{2} \mathrm{O}_{4}$ spinel [1,35-38]. For the nonpromoted $\mathrm{Ni} / \gamma-\mathrm{Al}_{2} \mathrm{O}_{3}$ catalyst the low temperature zone is very weak which is considered to be due to the low amount of bulk NiO particles. The high temperature zone strongly shifted to lower temperatures with increasing Yb doping content, which can be attributed to the weaker interaction of the NiO with the support and formation of non-stoichiometric Nickel aluminate spinels, instead of stoichiometric $\mathrm{NiAl}_{2} \mathrm{O}_{4}$. In addition, with increasing the loading of $\mathrm{Yb}$ in the $\mathrm{Ni} / \gamma-\mathrm{Al}_{2} \mathrm{O}_{3}$ catalysts, the intensity of the low temperature zone increases. Meanwhile, the TPR profiles of the 1 and 2\% Yb-promoted Ni/ $\gamma-\mathrm{Al}_{2} \mathrm{O}_{3}$ catalysts consisted of third reduction temperature zones $\left(455-585^{\circ} \mathrm{C}\right)$ with a maximum located at about $530{ }^{\circ} \mathrm{C}$ which can be attributed to the reduction of high dispersion NiO particles [35]. From the TPR profiles it can be seen that the reduction of $\mathrm{Ni}$ in the $\mathrm{NiO}$ particles on $\mathrm{Yb}$-promoted $\mathrm{Ni} / \gamma$ $\mathrm{Al}_{2} \mathrm{O}_{3}$ catalysts was significantly higher at lower temperatures than that observed for the non-doped catalyst.

The addition of $\mathrm{Yb}$ clearly made the $\mathrm{Ni} / \gamma-\mathrm{Al}_{2} \mathrm{O}_{3}$ catalyst more reducible which is due to the added $\mathrm{Yb}$ leading to the formation of a decreased extent of stoichiometric $\mathrm{NiAl}_{2} \mathrm{O}_{4}$ spinel, which is difficult to reduce [36]. It is thought that doping of ytterbium on $\mathrm{Ni} / \gamma-\mathrm{Al}_{2} \mathrm{O}_{3}$ catalyst reduces the chemical interaction between nickel and the support, promoting the formation of $\mathrm{NiO}$ and non-stoichiometric nickel aluminate spinel, instead of stoichiometric $\mathrm{NiAl}_{2} \mathrm{O}_{4}$ spinel. This is in agreement with the XRD and XPS results that were obtained. The aforementioned influence of $\mathrm{Yb}$ results in an increase in reducibility and stronger dispersion of nickel [36-39]. A similar effect of promoters has been also reported for Pt [7], Ce [38] and $\mathrm{ZrO}_{2}$ [9] in $\mathrm{Ni} / \mathrm{Al}_{2} \mathrm{O}_{3}$ catalyst.

The TPR results indicate that doping of the $\mathrm{Yb}$ up to $2 \mathrm{wt} \%$ in the $\mathrm{Ni} / \gamma-\mathrm{Al}_{2} \mathrm{O}_{3}$ catalyst not only increased the amount of the bulk NiO particles, but also produced highly dispersed NiO particles among the alumina framework that did not interact with $\mathrm{Al}_{2} \mathrm{O}_{3}$. The existence of these phases was verified by TEM/ EDX (Fig. 4).

The experimental results obtained in this study provide important information on the characteristics of $\mathrm{Yb}$ doped $\mathrm{Ni}$ alumina catalysts, which have been shown previously to have very good activity and stability for catalysing the dry reforming of methane. The differences observed in the characteristics of the catalysts doped with different levels of

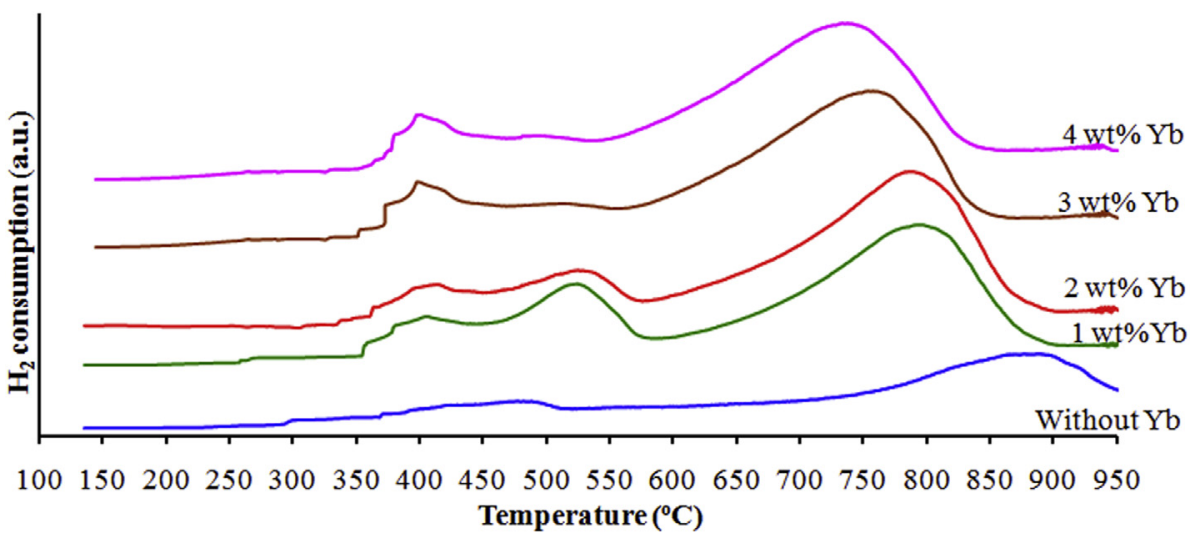

Fig. 7 - TPR profile of $\mathrm{Ni} / \gamma-\mathrm{Al}_{2} \mathrm{O}_{3}$ catalysts with different $\mathrm{Yb}$ loading. 
Yb obtained in this study are also in good agreement with the results previously reported on the catalytic activity of these catalysts [1].

\section{Conclusions}

In summary from the characterisation data obtained for nondoped and $\mathrm{Yb}$ doped $\mathrm{Ni} / \gamma-\mathrm{Al}_{2} \mathrm{O}_{3}$ it can be concluded that the main influence of $\mathrm{Yb}$ doping was to decrease the extent of $\mathrm{NiAl}_{2} \mathrm{O}_{4}$ formation. This was most likely due to $\mathrm{Yb}$ being incorporated into the $\mathrm{Al}_{2} \mathrm{O}_{3}$ support in preference to $\mathrm{Ni}$. The hindering of $\mathrm{NiAl}_{2} \mathrm{O}_{4}$ formation subsequently leads to a higher amount of $\mathrm{Ni}^{2+}$ in the catalyst pre-cursor being converted into metallic $\mathrm{Ni}$ in the final (reduced) catalyst/the $\mathrm{Ni}^{2+}$ in the precursor being more easily reduced. Hence the improved stability and activity of $\mathrm{Yb}$ doped $\mathrm{Ni} / \gamma-\mathrm{Al}_{2} \mathrm{O}_{3}$ catalysts for the dry reforming of methane is most likely due to the significant influence $\mathrm{Yb}$ doping has on the $\mathrm{Ni}$ in the aforementioned catalyst.

\section{Acknowledgements}

The authors gratefully acknowledge the facilities, and the scientific and technical assistance, of the Australian Microscopy \& Microanalysis Research Facility at the RMIT Microscopy \& Microanalysis Facility, at RMIT University and support from the Australian Synchrotron Research Program.

The authors thank Dr Selvakannan Periasamy and Dr. Jamie Booth for their helpful discussions, Dr. Jarrod Newnham and Dr. Samuel Ippolito for their help in automating the reactor system, and Dr. Justin Kimpton (Scientist - PD) and Moein Amin for their help acquiring the diffraction data at Australian synchrotron.

\section{R E F E R E N C E S}

[1] Amin MH, Mantri K, Newnham J, Tardio J, Bhargava SK. Highly stable ytterbium promoted $\mathrm{Ni} / \gamma-\mathrm{Al}_{2} \mathrm{O}_{3}$ catalysts for carbon dioxide reforming of methane. Appl Catal B 2012;119-120:217-26.

[2] Newnham J, Mantri K, Amin MH, Tardio J, Bhargava SK. Highly stable and active Ni-mesoporous alumina catalysts for dry reforming of methane. Int J Hydrogen Energy 2012;37(2):1454-64.

[3] Bradford MCJ, Vannice MA. $\mathrm{CO}_{2}$ reforming of $\mathrm{CH}_{4}$. Catal Rev 1999;41:1-42.

[4] Djinovi P, Batista J, Pintar A. Efficient catalytic abatement of greenhouse gases: methane reforming with $\mathrm{CO}_{2}$ using a novel and thermally stable $\mathrm{Rh}-\mathrm{CeO}_{2}$ catalyst. Int J Hydrogen Energy 2012;37:2699-707.

[5] Castro Luna AE, Iriarte ME. Carbon dioxide reforming of methane over a metal modified $\mathrm{Ni}-\mathrm{Al}_{2} \mathrm{O}_{3}$ catalyst. Appl Catal A 2008;343(1-2):10-5.

[6] Barroso-Quiroga MM, Castro-Luna AE. Catalytic activity and effect of modifiers on Ni-based catalysts for the dry reforming of methane. Int J Hydrogen Energy 2010;35:6052-6.
[7] García-Diéguez M, Finocchio E, Larrubia MA, Alemany LJ, Busca G. Characterization of alumina-supported Pt, Ni and PtNi alloy catalysts for the dry reforming of methane. J Catal 2010;274:11-20.

[8] de Souza VP, Costa D, dos Santos D, Sato AG, Bueno JMC. Ptpromoted $\alpha-\mathrm{Al}_{2} \mathrm{O}_{3}$-supported Ni catalysts: effect of preparation conditions on oxi-reduction and catalytic properties for hydrogen production by steam reforming of methane. Int J Hydrogen Energy 2012;37:9985-93.

[9] Albarazi A, Beaunier P, Da Costa P. Hydrogen and syngas production by methane dry reforming on SBA-15 supported nickel catalysts: on the effect of promotion by $\mathrm{Ce}_{0.75} \mathrm{Zr}_{0.25} \mathrm{O}_{2}$ mixed oxide. Int J Hydrogen Energy 2013;38:127-39.

[10] Eltejaei H, Bozorgzadeh HR, Towfighi J, Omidkhah MR, Rezaei M, Zanganeh R, et al. Methane dry reforming on Ni/ $\mathrm{Ce}_{0.75} \mathrm{Zr}_{0.25} \mathrm{O}_{2}-\mathrm{MgAl}_{2} \mathrm{O}_{4}$ and $\mathrm{Ni} / \mathrm{Ce}_{0.75} \mathrm{Zr}_{0.25} \mathrm{O}_{2}$ - $\gamma$-alumina: effects of support composition and water addition. Int $\mathrm{J}$ Hydrogen Energy 2012;37:4107-18.

[11] Sokolov S, Kondratenko EV, Pohl MM, Barkschat A, Rodemerck U. Stable low-temperature dry reforming of methane over mesoporous $\mathrm{La}_{2} \mathrm{O}_{3}-\mathrm{ZrO}_{2}$ supported $\mathrm{Ni}$ catalyst. Appl Catal B 2012;113-114:19-30.

[12] Luisetto I, Tuti S, Bartolomeo ED. Co and Ni supported on $\mathrm{CeO}_{2}$ as selective bimetallic catalyst for dry reforming of methane. Int J Hydrogen Energy 2012;37:15992-9.

[13] de Miguel SR, Vilella IMJ, Maina SP, San José-Alonso D, Román-Martínez MC, Illán-Gómez MJ. Influence of Pt addition to Ni catalysts on the catalytic performance for long term dry reforming of methane. Appl Catal A 2012;435-436:10-8.

[14] Li X, Hua Q, Yanga Y, Wanga Y, He F. Studies on stability and coking resistance of $\mathrm{Ni} / \mathrm{BaTiO}_{3}-\mathrm{Al}_{2} \mathrm{O}_{3}$ catalysts for lower temperature dry reforming of methane (LTDRM). Appl Catal B 2012;413-414:163-9.

[15] Wang N, Chu W, Zhang T, Zhao XS. Synthesis, characterization and catalytic performances of Ce-SBA-15 supported nickel catalysts for methane dry reforming to hydrogen and syngas. Int J Hydrogen Energy 2012;37:19-30.

[16] Kim TY, Kim SM, Lee WS, Woo SI. Effect and behavior of cerium oxide in $\mathrm{Ni} / \gamma-\mathrm{Al}_{2} \mathrm{O}_{3}$ catalysts on autothermal reforming of methane: $\mathrm{CeAlO}_{3}$ formation and its role on activity. Int J Hydrogen Energy 2013;38:6027-32.

[17] Jahangiri A, Pahlavanzadeh H, Aghabozorg H. Synthesis, characterization and catalytic study of Sm doped $\mathrm{LaNiO}_{3}$ nanoparticles in reforming of methane with $\mathrm{CO}_{2}$ and $\mathrm{O}_{2}$. Int $\mathrm{J}$ Hydrogen Energy 2013;37:9977-84.

[18] Yu X, Wang N, Chu W, Liu M. Carbon dioxide reforming of methane for syngas production over La-promoted NiMgAl catalysts derived from hydrotalcites. Chem Eng J 2012;209:623-32.

[19] Zhu J, Peng X, Yao L, Shen J, Tong D, Hu C. The promoting effect of $\mathrm{La}, \mathrm{Mg}$, $\mathrm{Co}$ and $\mathrm{Zn}$ on the activity and stability of Ni/ $\mathrm{SiO}_{2}$ catalyst for $\mathrm{CO}_{2}$ reforming of methane. Int J Hydrogen Energy 2011;36:7094-104.

[20] Li H, Xu H, Wang J. Methane reforming with $\mathrm{CO}_{2}$ to syngas over $\mathrm{CeO}_{2}$-promoted $\mathrm{Ni} / \mathrm{Al}_{2} \mathrm{O}_{3}-\mathrm{ZrO}_{2}$ catalysts prepared via a direct sol-gel process. J Nat Gas Chem 2011;20:1-8.

[21] Leofanti G, Padovan M, Tozzola G, Venturelli V. Surface area and pore texture of catalysts. Catal Today 1998;41:207-19.

[22] Hsu YF, Wang SF, Cheng TW. Effects of additives on the densification and microstructural evolution of fine $\mathrm{Al}_{2} \mathrm{O}_{3}$ powder. Mater Sci Eng 2003;A362:300-8.

[23] Jorgensen PJ, Westbrook JH. Role of solute segregation at grain boundaries during final-stage sintering of alumina. J Am Ceram Soc 1964;47(7):332-8. 
[24] Moulder JF, Stickle WF, Sobol PE, Bomben KD. In: Chastain J, Jr. King C Roger, editors. Handbook of X-ray photoelectron spectroscopy, physical electronics. Minnesota: Perkin-Elmer Corp Inc.; 1995.

[25] Valentini A, Carreno NLV, Probst LFD, Lisboa-Filho PN, Schreiner WH, Leite ER, et al. Role of vanadium in $\mathrm{Ni}: \mathrm{Al}_{2} \mathrm{O}_{3}$ catalysts for carbon dioxide reforming of methane. Appl Catal A 2003;255(2, 8):211-20.

[26] Uwamino Y, Ishizuka Y, Yamatera H. X-ray photoelectron spectroscopy of rare-earth compounds. J Electron Spectrosc Relat Phenom 1984;34:67-78.

[27] Bernhardt PV, Flanagan BM, Riley MJ, Wood BJ. An XPS study of an isomorphous trivalent lanthanoid series. J Electron Spectrosc Relat Phenom 2002;124:73-7.

[28] Pan TM, Huang WS. Effects of oxygen content on the structural and electrical properties of thin $\mathrm{Yb}_{2} \mathrm{O}_{3}$ gate dielectrics. J Electrochem Soc 2009;156(1):G6-11.

[29] Yan J, Gan G, Du J, Sun J. Second phases of (La, Nb)-codoped $\mathrm{TiO}_{2}$ varistor ceramic. J Phys 2009. http://dx.doi.org/10.1088/ 1742-6596/152/1/012067. Conference Series 152: 012067.

[30] Shannon RD. Revised effective ionic radii and systematic studies of interatomic distances in halides and chalcogenides. Acta Crystallogr 1976;A32:751-67.

[31] Yamamoto H, Akiyama K, Murakami Y. Densification behaviors and high-temperature characteristics of $\mathrm{Si}_{3} \mathrm{~N}_{4}$ sintered bodies using $\mathrm{Al}_{2} \mathrm{O}_{3}-\mathrm{Yb}_{2} \mathrm{O}_{3}$ additives. J Eur Ceram Soc 2006;26:1059-67.
[32] Dong B, Li CR, Lei MK, Lumin J. Green and red up-conversion emissions of $\mathrm{Er}^{3+}-\mathrm{Yb}^{3+}$-codoped $\mathrm{Al}_{2} \mathrm{O}_{3}$ powders prepared by the nonaqueous sol-gel method. J Lumin 2006. http:// dx.doi.org/10.1016/j.jlumin.2006.08.091.

[33] Levin EM, Cook LP, Robbins CR, McMurdie HF. Phase diagrams for ceramists. American Ceramic Society; 1989.

[34] Natesakhawat S, Oktar O, Ozkan US. Effect of lanthanide promotion on catalytic performance of sol-gel Ni/ $\mathrm{Al}_{2} \mathrm{O}_{3}$ catalysts in steam reforming of propane. J Mol Catal A Chem 2005;241:133-46.

[35] Junke X, Wei Z, Jihui W, Zhaojing LI, Jianxin M. Characterization and analysis of carbon deposited during the dry reforming of methane over $\mathrm{Ni} / \mathrm{La}_{2} \mathrm{O}_{3} / \mathrm{Al}_{2} \mathrm{O}_{3}$ catalysts. J Catal 2009;30(11):1076-84.

[36] Zhu X, Huo P, Zhang Y, Cheng D, Liu C. Structure and reactivity of plasma treated $\mathrm{Ni} / \mathrm{Al}_{2} \mathrm{O}_{3}$ catalyst for $\mathrm{CO}_{2}$ reforming of methane. Appl Catal B 2008;81:132-40.

[37] Liu BS, Au CT. Carbon deposition and catalyst stability over $\mathrm{La}_{2} \mathrm{NiO}_{4} /-\mathrm{Al}_{2} \mathrm{O}_{3}$ during $\mathrm{CO}_{2}$ reforming of methane to syngas. Appl Catal A 2003;244:181-95.

[38] Rynkowski JM, Paryjczak T, Lenik M. Characterization of alumina supported nickel-ruthenium systems. Appl Catal A 1995;126:257-71.

[39] Wang $\mathrm{S}$, Lu GQ. Role of $\mathrm{CeO}_{2}$ in $\mathrm{Ni} / \mathrm{CeO}_{2}-\mathrm{Al}_{2} \mathrm{O}_{3}$ catalysts for carbon dioxide reforming of methane. Appl Catal B 1998;19(3-4):267-77. 